\title{
MINHAS LEMBRANÇAS DE MURILO
}

Jaime Prado gouvêA

Mineiro de Belo Horizonte, autor de Fichas de Vitrola e Outros Contos (Ed. Record, 2007) e O Altar das Montanha de Minas (Ed. Record, 2010). É diretor do Suplemento Literário de Minas Gerais.
No dia 12 de setembro de 1991, uma quintafeira, Murilo Rubião me telefonou pedindo que o acompanhasse até o mezanino do Edifício Arcângelo Maleta, no Centro de Belo Horizonte, onde seria exibido o curtametragem $O$ pirotécnico Zacarias, de Rodolfo Magalhães, baseado em seu conto homônimo. Era um prelúdio à exposição "Murilo Rubião - Construtor do Absurdo", a ser aberta na semana seguinte no Palácio das Artes. Murilo morava no prédio ao lado, mas, como andava com a saúde abalada, me fez o tal pedido, que tive o prazer de atender, é claro. Encontrei-o na porta do seu apartamento, descemos de elevador os cinco andares até a rua e, virando uma entrada à direita, subimos para a Cantina do Lucas, onde alguns amigos o esperavam. Logo estávamos no mezanino, onde fora improvisada uma "sala" de cinema. Ao final da projeção, deixei-o com seus amigos e fui embora. Foi a última vez que o vi com vida.

Na noite do dia 16, quatro dias antes da abertura da exposição, Murilo chegou ao Palácio das Artes, mas para ser velado. Parecia enredo de conto dele, com todo o clima de absurdo pairando no grande saguão do teatro, como se aquele evento triste fizesse parte da mostra. Mas era apenas a terrível banalidade do fim. Sua última ação mágica seria manter-se vivo para sempre nos 33 contos que esculpiu com rigor e sensibilidade, disso nós tínhamos certeza.

Digo "nós" porque, presentes ou não em pessoa, os muitos jovens escritores que foram 
impulsionados por Murilo estavam lá para despedir-se dele. Eu mesmo revia o momento em que fui apresentado ao mítico escritor, então secretário do Suplemento Literário do "Minas Gerais" - que criara em 1966 -, por seu redator Humberto Werneck, que Ihe sugerira meu nome para substituir na Revisão o poeta João Paulo Gonçalves, que pedira demissão para se casar. A justificativa da indicação poderia ser o prêmio conquistado no Concurso de Contos do Paraná 1969, na categoria "Estudante".

Dividi a mesa nos fundos da redação com outro poeta revisor, Adão Ventura. Mais à frente trabalhavam, surrealisticamente falando, os redatores Carlos Roberto Pellegrino, Márcio Sampaio e o próprio Humberto, o diagramador Lucas Raposo, o subsecretário Rui Mourão e, na mesa de frente para nós, o chefe Murilo Rubião, sempre com o terno e a gravata, atrás da piteira e dos óculos. Apesar do aspecto formal, logo eu veria que, mesmo sem deixar de exercer sua autoridade - a seu modo: afável e muitas vezes divertido -, que ele era mais um colega nosso. No mundo extraordinário do pai do Teleco, o Coelhinho, não havia diferença de idade.

Mas havia também firmeza e coragem para fazer um jornal cultural em plena ditadura. o Suplemento era então atacado pelos mais enferrujados representantes da subliteratura, que pregavam contra as novidades de estilo e a criatividade que as novas gerações procuram trazer, e pelo autoritarismo mais retrógado de parte da tradicional família mineira e do clero medieval que imperava entre nossas montanhas. Nada disso fez Murilo recuar em seu projeto de fazer uma publicação na qual mesclava iniciantes e autores consagrados, muito deles companheiros de geração do próprio Murilo. 0 respeito que sua trajetória 
cultural impunha blindava todas as experiências "subversivas" que arriscávamos.

Ele tinha um estilo próprio de administrar o Suplemento. Embora confiasse em sua equipe, sempre levava os originais para casa e voltava com o número já programado. Mas dando a impressão de que o planejamento das edições era de todo o grupo. Sempre que o bafo da repressão pairava sobre nós, ele nos defendia indo, se fosse possível, até o governador, fazendo uso do respeito que tinha angariado desde os tempos em que serviu no Palácio da Liberdade e do prestígio que conquistara entre os grandes da literatura brasileira como Carlos Drummond de Andrade, Mário de Andrade, Fernando Sabino, Otto Lara Resende, Paulo Mendes Campos, Hélio Pellegrino, Eduardo Frieiro, Autran Dourado.

Meio século depois daquela época, fundamental para o surgimento de futuros grandes autores - frequentavam a redação, por exemplo, os jovens Luiz Vilela e Sérgio Sant'Anna, que ali conviviam com nomes consagrados como Emílio Moura, Affonso Ávila, Ildeu Brandão, Bueno de Rivera, Laís Corrêa de Araújo e outros - , lembro a face quase paterna desse radical solteirão no convívio com seus funcionários. Eu mesmo posso citar com ternura dois momentos da minha vida que foram marcados pela mão protetora do Ex-Mágico. O primeiro, em 1974, quando ele fez questão de ir à minha casa pedir permissão ao meu pai para que eu viajasse com ele para uma semana literária na cidade de São Gotardo, quando eu já tinha 29 anos de idade! 0 outro, uns três anos depois, quando ele me deu uma bronca ao saber que meu noivado havia terminado. De nada adiantou eu dizer a ele que quem terminou foi ela, pois me condenou assim mesmo: "Você não podia deixar isso 
acontecer!" Fazer o quê? A preocupação dele conosco ia além da literatura.

Seu zelo pela cria fez Murilo evitar o fim do Suplemento quando, em 1975, inconformado com interferências externas que o jornal vinha sofrendo, o então secretário Wander Piroli se demitiu. Solidário, o pessoal que fazia o jornal deixou de colaborar e a publicação ficou à deriva. Murilo foi ao Palácio e, na tentativa de contornar a crise, indicou o escritor Wilson Castelo Branco, que trabalhava na assessoria do governador, para o cargo que ficara vago. Nos oito anos que se seguiram, o Suplemento, agora sem Murilo e equipe, fartou-se de publicar muitos de seus antigos desafetos, cujas colaborações medíocres justificavam o desprezo que sofreram antes de ficarem com o pasto liberado pela saída do pessoal antigo. Só em 1983, quando foi nomeado diretor da Imprensa Oficial, Murilo retomou as rédeas do Suplemento e trouxe o pessoal de volta. Sob a direção de Duílio Gomes, Manoel Lobato, Sebastião Nunes e eu recolocamos o jornal no patamar do qual fora apeado. Mesmo com todos aqueles tropeços, o Suplemento sobreviveu até hoje, 55 anos depois de sua criação.

Em 2016, na comemoração do cinquentenário do SLMG e do centenário de Murilo Rubião, sua estátua foi inaugurada no jardim da Biblioteca Pública do Estado de Minas Gerais, em cujo prédio funciona hoje o Suplemento. A obra, que representa o Murilo chegando ao prédio com um exemplar do jornal embaixo do braço, confirma que ele nunca nos deixou.

Humberto Werneck, o autor de $O$ desatino da rapaziada e de muitos livros de crônicas, sempre diz que o Murilo foi uma das três pessoas fundamentais em sua vida. Como quase irmão 
do Humberto (somos amigos há 62 anos), assino embaixo esse reconhecimento. $E$, passados 30 de sua despedida, lembrando-me da sua figura deitada entre flores no saguão do Palácio das Artes, entendi afinal que ele estava apenas indo buscar a estrelinha quase invisível ao lado da lua que Bárbara lhe pedira no fecho de um de seus mais belos contos. 